REFERENCES

1. Bertuccio $P$, Rosato $V$, Andreano A, Ferraroni M, Decarli A, Edefonti $\mathrm{V}$, La Vecchia C. Dietary patterns and gastric cancer risk: a systematic review and meta-analysis. Ann Oncol. 2013; 24(6):1450-8.

2. Bracale U., Pignata G, Lirici MM., et AL. Laparoscopic gastrectomies for cancer: The ACOI-IHTSC national guidelines. Minimally Invasive Therapy. 2012; Early Online, 1-7

3. Brasil. Ministério da Saúde. Instituto Nacional do Câncer. Disponível em:<http://www2.inca.gov.br/wps/wcm/connect/tiposdecancer/ site/home/estomago. Acesso em janeiro de 2014.

4. Chen K, Xu XW, Mou YP, Pan Y, Zhou YC, Zhang RC, Wu D. Systematic Review and meta-analysis of laparoscopic and open gastrectomy for advanced gastric cancer. World J Surg Oncol. 2013;11:182.

5. Fitzgerald RC, Hardwick R, Huntsman D, Carneiro F, Guilford P, Blair V, Chung DC, Norton J, Ragunath K, Van Krieken JH, Dwerryhouse S, Caldas C; International Gastric Cancer Linkage Consortium. Hereditary diffuse gastric cancer: updated consensus guidelines for clinical management and directions for future research. J Med Genet. 2010 Jul;47(7):436-44.

6. Mastoraki A, Danias N, Arkadopoulos N, Sakorafas G, Vasiliou P, Smyrniotis V. Prophylatic total gastrectomy for hereditary diffuse gastric cancer. Review of the literature. Surg Oncol 2011; 4:223-6.

7. Matsukuma KE, Mullins FM, Dietz L, Zehnder JL, Ford JM, Chun NM Schrijver I. Hereditary diffuse gastric cancer due to a previously undescribed CDH1 splice site mutation. Hum Pathol. 2010;41:1200-3.

8. Norton JA, Ham CM, Van Dam J, Jeffrey RB, Longacre TA, Huntsman DG, Chun N, Kurian AW, Ford JM. CDH1 truncating mutations in the E-cadherin gene: an indication for total gastrectomy to treat hereditary diffuse gastric cancer. Ann Surg. 2007 Jun;245(6):873-9.

9. Pandalai PK, Lauwers GY, Chung DC, Patel D, Yoon SS. Prophylactic total gastrectomy for individuals with germline $\mathrm{CDH} 1$ mutation. Surgery 2011;149:347-55

10. Seevaratnam R, Coburn N, Cardoso R, Dixon M, Bocicariu A, Helye $\mathrm{L}$. A systematic review of the indications for genetic testing and prophylactic gastrectomy among patients with hereditary diffuse gastric cancer. Gastric Cancer. 2012;15:153-63

ABCDDV/1111

2015;28(2):151

DOI:http://dx.doi.org/10.1590/ S0102-67202015000200018

\section{RETRORECTAL TUMOR: A CASE REPORT OF A PATIENT WITH "SCHWANNOMA"}

Tumor retrorretal: relato de caso de um paciente com "schwanoma"

Henrique Perobelli SCHLEINSTEIN; Paulo Antonio Lemos CURIATI; Marcelo AVERBACH; Pedro POPOUTCHI

From the Hospital São Camilo Pompéia (São Camilo Pompéia Hospital), São Paulo, SP, Brazi

Financial source: none

\section{Correspondence:}

Henrique Perobelli Schleinstein

E-mail: henriqueperobelli@gmail.com

Received for publication: 22/04/2014 Accepted for publication: 24/02/2015

\section{INTRODUCTION}

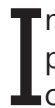
njuries that affect the presacral space are rare, and are part of a heterogeneous group of entities of primary

concern to colorectal surgeons. These lesions are located in anatomically difficult area to be addressed, hence the need for prior surgical planning, as well as knowledge of the major diseases that affect this region.

The incidence of these lesions varies from 1: 40.000 to 1: $630,000^{7}$, being more common in females between 40 and 60 years $^{8}$

\section{CASE REPORT}

Man of 94 years showed changes in bowel habits few months ago. Digital rectal examination showed solid pelvic mass with no apparent invasion of the rectal mucosa; it is not possible to predict its upper limit. Computed tomography of the pelvis showed solid-cystic lesion in proximity to the sacrum bone and rectum, with apparent cleavage plane between adjacent structures (Figure 1). He underwent transperitoneal resection of the lesion. Major bleeding occurred during surgery, which was controlled, requiring blood transfusion with four blood cell concentrate units.

Postoperative was without morbidity and discharged on the $7^{\text {th }}$ day after surgery. The pathology confirmed it was schwannoma of low-grade without evidence of malignancy (Figure 2).

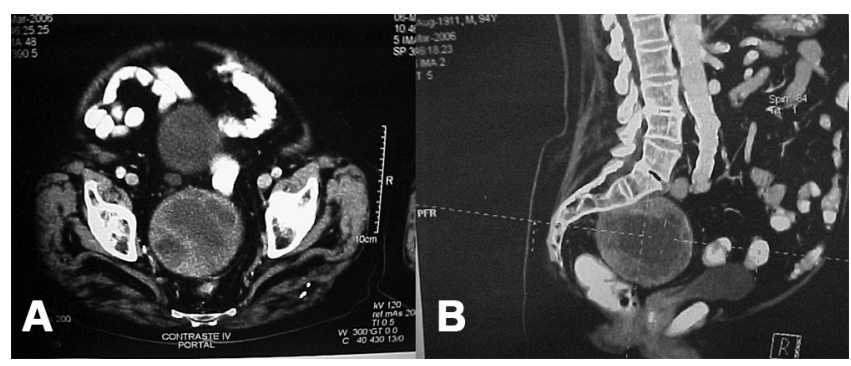

FIGURE 1 - Tumor images located in the presacral space
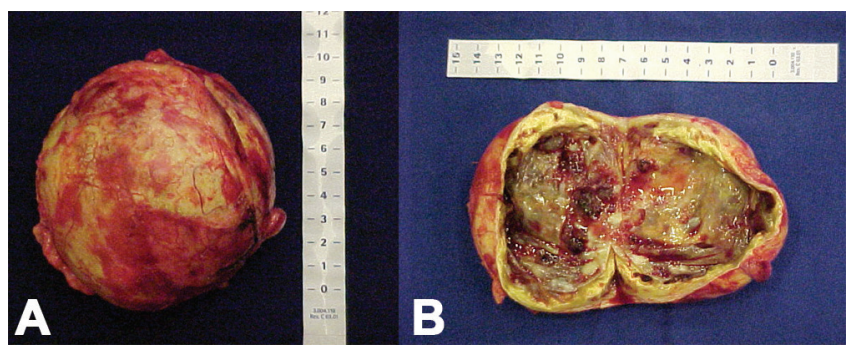

FIGURE 2 - Encapsulated tumor (10 cm in diameter - A) and open aspect (B) showing mucoid material inside

DISCUSSION

Although most retrorectal lesions are congenital, most patients do not have a previous positive family history; the most common clinical presentation is asymptomatic mass found to proctologic examination ${ }^{5}$. The retrorectal masses are palpable on rectal exam by up to $97 \%$ of cases $^{7}$.

Due to the angular change caused by the puborectalis muscle mass patients often have changes in bowel habits with a tendency to constipation, feeling of incomplete evacuation or thin stools.

A flexible sigmoidoscopy is useful for viewing the invasion of the rectal mucosa by the tumor and its upper limit, for correct surgical management.

Imaging tests are essential for accurate diagnosis, and the MRI is superior to CT in the characterization of pelvic masses for the presence of bone invasion or neural involvement ${ }^{2}$.

Treatment is mainly surgical. Many of these injuries, 
despite the benign appearance, may contain malicious elements or potentiality for malignant degeneration in the medium term, and the risk of infection in benign cysts. This patient was discharged on the seventh postoperative day, with uneventful recovery.

The resection of the coccyx is not recommended unless there is suspicion of involvement by malignant disease ${ }^{3}$. As far as rectum is often densely adhered to the tumor, should be carried out careful dissection, to avoid injury.

There are three types of surgical approach: anterior or abdominal transperitoneal or extra-peritoneal, conventional or laparoscopic access; the posterior approach; and combined abdominosacral route.

The anterior approach is used for high lesions (with caudal end until the level S4) without evidence of sacral engagement. The rectum is folded laterally and the median sacral artery is usually linked with the dissection and tumor is enucleated ${ }^{2}$.

The latter approach is preferred for smaller, benign lesions that do not extend beyond the level S4. This route is used when the presence of neural involvement or for better viewing and preservation ${ }^{1}$.

Tumors of major proportions exceeding proximal and distal S4 level are more easily operated via abdominosacral ${ }^{2}$ route. The resection can be performed synchronously with the patient in the lateral position or sequentially with the change in position after each stage of the operation. The benefit of the combined approach includes the ability to display structures such as ureter, nerve and sacral iliac vessels, particularly important in cases where there is the need to perform partial sacrectomy, especially in chordoma.

The adjuvant therapies have only a secondary role in the management of tumors in retrorectal space. In cases where radical surgery is contraindicated, palliative radiotherapy has been carried out, except for chordoma, classically radioresistant.

The survival of benign tumors approaches to $100 \%$ in most studies ${ }^{7}$. However relapse is not uncommon. Development of cysts relapses up to $15 \%^{1}$. Approximately $9-45 \%$ of retrorectal malignant tumors are most commonly solids than cystic, with recurrence rates of $45 \%$; five year survival rate is about 8 to $17 \%$.

\section{REFERENCES}

1. Althausen PL, Schneider PD, Bold RJ, et al. Multimodality management of giant cell tumor arising in the proximal sacrum: case report. Spine 2002;27:E361-5.

2. Bohm B, Milsom JW, Fazio VWetal.Ourapproach tothemanagement of congenital presacral tumors in adults. Int J Colorectal Dis 1993; 8: $134-8$.

3. Cody HS, Marcove RC, Quan SH, et al. Malignant retrorectal tumors 28 years' experience at Memorial Sloan Kettering Cancer Center. Dis Colon Rectum 1981;24: 501-6.

4. Glasgow SC, Birnbaum EH, Lowney JK et al. Retrorectal Tumors: A Diagnostic and Therapeutic Challenge. Dis Colon Rectum 2005; 48:1581-1587.

5. Hjermstad BM, Helwing EB. Tailgut Cyst. Report of 53 cases. Am J Clin Pathol 1988; 89:139-47.

6. Hobson $\mathrm{KH}$, Ghaemmaghami V, Roe JP, et al. Tumor of the Retrorectal Space. Dis Colon Rectum 2005; 48:1964-1974.

7. Jao SW, Beart RW, Spencer RJ et al: Mayo Clinic experience, 19601979. dis Colon Rectum 1985;28:644-52.
8. Mc Cune WS, Management of sacrococcygeal tumors. Ann Surg 1964:159:911-8.

ABCDDV/1112

ABCD Arq Bras Cir Dig

Letter to the Editor

2015;28(2):152

DOI:http://dx.doi.org/10.1590/ S0102-67202015000200019

\section{AN EXTREMELY RARE COMPLICATION OF MECKEL'S DIVERTICULUM: ENTEROCUTANEOUS FISTULZATION OF UMBUICAL HERNIA}

\author{
Complicação rara de divertículo de Meckel: \\ fistulização enterocutânea através de hérnia umbilical
}

Oztekin CIKMAN ${ }^{1}$,Hasan Ali KİRAZ ${ }^{2}$,Omer Faruk OZKAN ${ }^{1}$, Gurhan ADAM ${ }^{3}$, Ahmet CELIK ${ }^{1}$, Muammer KARAAYVAZ ${ }^{1}$

From ${ }^{1}$ Canakkale 18 March University, Faculty of Medicine, Department of General Surgery, Canakkale; ${ }^{2}$ Canakkale 18 March University, Faculty of Medicine, Department of Anestesiology, Canakkale; ${ }^{3}$ Canakkale 18 March University, Faculty of Medicine, Department of Radiology, Canakkale, Turkey

\section{Correspondence:}

Oztekin Cikman

E mail:droztekin67@hotmail.com

Financial source: none Conflicts of interest: none

Received for publication: 04/02/2014 Accepted for publication: 11/12/2014

INTRODUCTION

$\mathrm{M}$ eckel's diverticulum is the most common malformation of the gastrointestinal tract with an incidence of $2 \%$ of the population. This congenital anomaly results from incomplete yolk duct development ${ }^{1}$. Meckel's diverticulum has a complication rate of $4-6 \%$. Most common complications are haemorrhage, perforation, obstruction and inflammation ${ }^{4}$. It is mostly asymptomatic and most often diagnosed when complications occur. Also it may be diagnosed incidentally during laparoscopy or laparatomy for unrelated conditions ${ }^{1}$

Fistula formation (between abdominal organs), herniation (of abdominal wall), and Littre hernia (protrusion of a Meckel's diverticulum through an abdominal wall defect) are well-described complication. However, umbilical herniation of Meckel's diverticulum is rare ${ }^{3}$. Herein is presented a case with enterocutaneous fistula between Meckel's diverticulum and umbilicus associated with umbilical hernia.

\section{CASE REPORT}

A 40-year-old man was admitted to the department of General Surgery with a $24 \mathrm{~h}$ history of abdominal pain focused on the umbilical region, as well as fever, anorexia and vomiting. He had a history of previous umbilical abscess drainage five years ago. He reported no other medical history. Examination of the abdomen showed tenderness over the umbilical region without abdominal guarding and rigidity. A leakage of intestinal fluid through an opening (an external fistula orifice) was determined inside the umbilicus. There was no increase in local heat, swelling or edema. The laboratory findings, including complete blood count and electrolytes, and abdominal X-ray showed no abnormality. Abdominal ultrasound showed a well-limited 